\title{
CHLOROPHYLL-PROTEINS OF THYLAKOIDS FROM WILD-TYPE AND MUTANTS OF BARLEY (HORDEUM VULGARE L.)
}

\author{
by \\ OTTO MACHOLD', DAVID J. SIMPSON and BIRGER LINDBERG MØLLER
}

Department of Physiology, Carlsberg Laboratory

Gamle Carlsbergvej 10, DK-2500 Copenhagen, Valby

and

ZZentralinstitut für Genetik und Kulturpflanzenforschung der Akademie der Wissenschaft der DDR, 4325 Gatersleben, DDR

Recipient of a Danish State Scholarship 1979.

Keywords: Absorption spectra, chlorina- $f 2$, light-harvesting complex, fluorescence, SDSpolyacrylamide gel electrophoresis, urea gel, viridis $-m^{29}$, viridis $-n^{34}$, viridis $-z d^{69}$.

\begin{abstract}
A sodium dodecyl sulphate-polyacrylamide gel electrophoresis system is described that resolves wild-type barley thylakoid components into ten chlorophyll-containing bands, plus free chlorophyll. Many of these bands have been characterised with respect to their absorption spectra and polypeptide composition. The identity and probable function of eight bands were established by comparison of the wild-type pattern with those of isolated light-harvesting chlorophyll $a / b$-protein complex and a number of nuclear gene mutants of barley. It was found that the mutant chlorina- $f$, which lacks chlorophyll $b$, contains only three chlorophyll $a$-proteins designated $\mathrm{Ch}_{\mathrm{a}} \mathrm{P} 1, \mathrm{Chl}_{\mathrm{a}} \mathrm{-P} 2$ and $\mathrm{Ch}_{\mathrm{a}} \mathrm{P} 3$ according to a new system of nomenclature proposed in this paper. $\mathrm{Chl}_{\mathrm{a}} \mathrm{-P} 1$ contains the reaction centre of photosystem I (P700) and with the aid of the mutant viridis- $m^{29}, \mathrm{Chl}_{2}-\mathrm{P} 3$ was deduced to be the most likely site of the reaction centre (P680) of photosystem II.

Two chlorophyll $a / b$-proteins were found, which differed in their $a / b$ ratios and which are thought to play a role in light-harvesting or light-focusing. These were designated $\mathrm{Chl}_{\mathrm{a}} / \mathrm{b}-\mathrm{P} 1$ and $\mathrm{Chl}_{\mathrm{a}} / \mathrm{b}-\mathrm{P} 2$, the latter being found in multimeric complexes designated $\mathrm{Chl}_{a} / \mathrm{b}-\mathrm{P} 2^{*}, \mathrm{Chl}_{a} / \mathrm{b}-\mathrm{P} 2^{* *}$ and $\mathrm{Chl}_{a} / \mathrm{b}-\mathrm{P} 2^{* * *}$, in order of increasing apparent molecular weight. In addition to these eight bands, there were two chlorophyll-containing bands in the wild-type pattern that were not $\mathrm{Chl}_{\mathrm{a} / \mathrm{b}}-\mathrm{P} 2$ complexes and which were called $\mathrm{Chl}-\mathrm{P}$ bands until further characterised.
\end{abstract}

Abbreviations: $\mathrm{Chl}=$ chlorophyll, $\mathrm{Chl}-\mathrm{P}=$ chlorophyll-protein, $\mathrm{CPI}=$ chlorophyll-protein complex $\mathrm{I}$, CPII = chlorophyll-protein complex II, DTT $=$ dithiothreitol, HEPES $=\mathrm{N}-(2$-hydroxyethyl)-piperazine-N'-2 -ethane sulphonic acid, $\mathrm{kD}=$ kilodalton, $\mathrm{LHC}=$ light-harvesting complex, $\mathrm{SDS}=$ sodium dodecyl sulphate, TEMED $=\mathrm{N}, \mathrm{N}, \mathrm{N}^{*}, \mathrm{~N}^{*}$-tetramethylethylenediamine, Tricine $=\mathrm{N}$-(tris-(hydroxymethyl)-methyl)glycine, Tris = tris-(hydroxymethyl)aminomethane. 


\section{INTRODUCTION}

Chloroplast thylakoids can be solubilised by the ionic detergent sodium dodecyl sulphate (SDS) and the polypeptide components separated by polyacrylamide gel electrophoresis. The procedures used until recently were capable of resolving only three chlorophyll-containing bands $(8,27,34)$ designated, in order of increasing electrophoretic mobility, chlorophyllprotein complex I (CPI), chlorophyll-protein complex II (CPII) and free chlorophyll (34). These chlorophyll proteins have been isolated from many species, and are sensitive to denaturation by heat (11), unfavourable $\mathrm{pH}(22)$ and strongly reducing conditions (MACHOLD, unpublished results).

The chlorophyll-proteins observed on polyacrylamide gels are believed to reflect the existence of chlorophyll-proteins in the native membrane, but much or all of the free chlorophyll on the gel may derive from denaturation of CPI and CPII and other unknown chlorophyll-proteins (see ref. 25). With this possible denaturation in mind, electrophoretic procedures have been designed to increase the stability of the native chlorophyll-proteins. This has been achieved mainly by decreasing the ratio of SDS to protein when solubilising the thylakoids $(13,15,24$, $29)$, running the gels at low temperature $(2,12$, $13,15,16,18)$, and/or by substituting some or all of the SDS with non-ionic detergents $(2,13$, 18,25 ), usually in combination with thicker gels. Under such conditions, between one and three new chlorophyll-containing bands have been reported with electrophoretic mobilities between CPI and CPII $(2,12,13,15,16,17,18$, $27,29,30,36)$ and up to two bands with mobilities lower than CPI $(2,28)$. It is difficult, however, to compare the results from different laboratories because of differences in plant material, solubilisation procedures, type of buffer system, and conditions during electrophoresis.

We have examined the chlorophyll-protein composition of wild-type barley thylakoids under conditions of gentle solubilisation and electrophoresis which yield ten chlorophyllcontaining bands, plus free chlorophyll. Many of these bands were identified by comparison with the chlorophyll-containing band patterns of isolated light-harvesting complex (LHC) and certain barley nuclear gene mutants. A new nomenclature system was devised since published nomenclature is inadequate to name the large number of new chlorophyll-containing bands described in this paper.

\section{MATERIALS AND METHODS}

\subsection{Plant material}

Seeds of wild-type barley (Hordeum vulgare cv. Svalöfs Bonus) were germinated in plastic trays containing vermiculite moistened with tap water. Seedlings were harvested after growing for 7 days at $20^{\circ} \mathrm{C}$ in continuous white light (1,700 lux provided by Sylvania F48T12-GROVHO Gro-lux fluorescent lights). Seedlings from the barley mutant chlorina- $f 2$, which lacks chlorophyll $b$ (5), were grown under the same conditions. The nuclear gene mutants viridis$m^{29},-n^{34}$ and $-z d^{69}$ do not survive in the field and the stocks are maintained in the heterozygous condition. The mutant progeny arising from heterozygous plants were identified by their paler green colour and separated from the wild-type phenotype after growing for 7 days at $20^{\circ} \mathrm{C}$ in continuous white light.

\subsection{Isolation of thylakoids}

The method for isolation and purification of thylakoids was a modification of that previously described (20). The grinding medium consisted of $0.4 \mathrm{M}$-sucrose, $200 \mathrm{~mm}-\mathrm{NaCl}$ and $50 \mathrm{~mm}$-Tricine/ $\mathrm{NaOH}, \mathrm{pH} 7.9$. Precooled leaves were homogenised in 3 volumes of grinding medium at $4{ }^{\circ} \mathrm{C}$, using a kitchen blender with replaceable razor blades (21). The resulting slurry was filtered through 2 layers of $31 \mu \mathrm{m}$ nylon gauze and centrifuged $5 \mathrm{~min}$ at $1,400 \mathrm{~g}$ (wild-type) or $8,000 \mathrm{~g}$ (mutants). The chloroplast pellet was suspended and osmotically shocked in $25 \mathrm{~mm}$ HEPES/ $\mathrm{NaOH}, \mathrm{pH} 7.5,10 \mathrm{~mm}$-EDTA and centrifuged $5 \mathrm{~min}$ at $10,000 \mathrm{~g}$. After two additional washes, the final pellet was suspended in a small volume $(3-10 \mathrm{ml})$ of $1.90 \mathrm{M}$-sucrose, $25 \mathrm{~mm}$ HEPES/NaOH, pH7.5, 5mm-EDTA using a motor driven teflon pestle. To each centrifuge tube was added approximately $5 \mathrm{ml}$ of thylakoid suspension, which was overlayered and topped up with $1.14 \mathrm{M}$-sucrose, $25 \mathrm{~mm}$-HEPES/ $\mathrm{NaOH}$, $\mathrm{pH} 7.5$, 5mм-EDTA (wild-type) or $0.93 \mathrm{M}$ - 
sucrose, 25mm-HEPES/NaOH, pH7.5, 5mmEDTA (mutants), and centrifuged at $4{ }^{\circ} \mathrm{C}$ for 30 $\min$ at $140,000 \mathrm{~g}$ using an $\mathrm{SW}-40$ rotor in a Beckman ultracentrifuge. The thylakoids floated to the sucrose-sucrose interface and were collected with a syringe. The sample was diluted with 25mm-HEPES/NaOH, pH7.5, 10mm-EDTA and centrifuged for $10 \mathrm{~min}$ at $48,000 \mathrm{~g}$. In some experiments, this final wash was replaced by two washes with distilled water to remove as much of the bound ribulose-1,5-bisphosphate carboxylase as possible.

\subsection{Solubilisation procedures}

The solubilisation procedure depended on the type of gel system being used. When it was desired to separate chlorophyll-proteins, the freshly prepared thylakoid pellets from the final centrifugation were resuspended until fluid in a small volume of distilled water using a glass rod. A sufficient volume of this suspension was added to distilled water containing an amount of stock solution of $10 \%$ SDS in 1.5M-Tris/ $\mathrm{H}_{2} \mathrm{SO}_{4}$, pH9.00 buffer, so that the final ratio of SDS: chlorophyll $(\mathrm{w} / \mathrm{w})$ was $3.6: 1$, and the final concentration of SDS was $1 \%$. Typically this involved adding $60 \mu \mathrm{l}$ of $10 \%$ SDS stock solution to $340 \mu \mathrm{l}$ of distilled water, followed by $200 \mu \mathrm{l}$ of wild-type thylakoid suspension. When using mutant thylakoids, an SDS: protein ratio of about 0.7: 1 was used, and for isolated lightharvesting complex, an SDS: protein ratio of 1.1: 1 , with a final concentration of SDS of $1 \%$. The resulting mixtures were gently stirred with a glass rod and centrifuged at $18{ }^{\circ} \mathrm{C}$ for $15 \mathrm{~min}$ at $40,000 \mathrm{rpm}$ in a $50 \mathrm{Ti}$ rotor in a Beckman ultracentrifuge. This resulted in a small pellet of non-solubilised material and a dark green clear supernatant which was used immediately for polyacrylamide gel electrophoresis. It was found that chlorophyll-proteins could be obtained from stored material if a small amount of solid DTT was added to the concentrated purified thylakoid suspension and aliquots frozen in liquid nitrogen prior to storage at $-20^{\circ} \mathrm{C}$. For gel electrophoresis under more strongly denaturing conditions, the amount of SDS was doubled so that the final concentration was $2 \%$. In addition, solid DTT was added to the samples, to a final concentration of $2-4 \%$, prior to electrophoresis. Because the material was so concentrated, sample volume per track varied between 2 and $5 \mu$ l.

\subsection{Gel electrophoresis}

Three different electrophoretic systems were used in the course of these experiments, and are listed in Table I. A slab-gel apparatus, modified from the design of STudiER (32) was used for all three gel types. The components of the Trisglycine/Tris-sulphate gel (system IV) are given in Table II, and those for systems II and III are as previously described (23).

Gels containing chlorophyll-protein bands were photographed without removing the glass plates using Agfacolor $50 \mathrm{~S}$ professional film with transmitted diffuse illumination from fluorescent tubes. The fluorescence from the chlorophyll-proteins was recorded using the same film with a combination of UV (B + W 010) and dark red $(B+W$ 091) filters and gels were illuminated from below with long wavelength UV light from a Chromato-Vue transilluminator, Model C-62 (Ultra-Violet Products, Inc., San Gabriel, California, USA).

Absorption spectra of the chlorophyll-protein bands in the gels were recorded with an AmincoChance DW-2a dual wavelength spectrophotometer. Chlorophyll-proteins for re-electrophoresis were obtained by cutting out the appropriate green bands from $2.4 \mathrm{~mm}$ thick unfixed gels with a scalpel and homogenising in a small volume of $\mathrm{Na}$ borate $/ \mathrm{HCl}$ substance buffer $(\mathrm{pH}$ 8.9 ) in a conical Potter-Elvehjem homogeniser with a motor driven teflon pestle. The resulting suspension was centrifuged in a benchtop centrifuge. After re-extraction of the resulting pellet, followed by centrifugation, the supernatants were pooled. The supernatant was then centrifuged in a SS-34 rotor (Sorvall) for $10 \mathrm{~min}$ at $48,000 \mathrm{~g}$ to pellet the residual polyacrylamide. and filtered through a Millipore filter (GSWT01300, $0.2 \mu \mathrm{m}$ pore size) attached to a syringe. The green filtrate was loaded into an Amicon microultrafiltration system $8 \mathrm{MC}$ operated at $5 \mathrm{~kg} \cdot \mathrm{cm}^{-2}$ with a PM10 filter, and concentrated to about $200 \mu \mathrm{l}$.

Gels were fixed in methanol: acetic acid: water (5:5:1) and stained in either Coomassie brilliant blue G-250 or R-250(0.05\% solution in fixative) and destained with $7 \%$ acetic acid, followed by 
Table I

Description of electrophoretic systems

\begin{tabular}{|c|c|c|c|}
\hline & System II & System III & System IV \\
\hline Upper reservoir buffer & $\begin{array}{l}\text { Tris-borate, } \mathrm{pH} 8.64 \\
0.1 \% \text { SDS }\end{array}$ & $\begin{array}{l}\text { borate-HC1, pH } 8.00 \\
0.1 \% \text { SDS }\end{array}$ & $\begin{array}{l}\text { Tris-glycine, pH } 9.00 \\
0.1 \% \text { SDS }\end{array}$ \\
\hline Stacking gel buffer & Tris-sulphate, $\mathrm{pH} 6.10$ & Tris- $\mathrm{HCl}, \mathrm{pH} 8.90$ & Tris-sulphate, $\mathrm{pH} 9.00$ \\
\hline Stacking gel & $\begin{array}{l}6 \% \text { acrylamide } \\
\text { acryl } / \mathrm{bis}=30: 0.8 \\
0.1 \% \mathrm{SDS} \\
12 \mathrm{~mm}\end{array}$ & $\begin{array}{l}6 \% \text { acrylamide } \\
\text { acryl } / \text { bis }=30: 0.8 \\
0.1 \% \text { SDS } \\
4 \mathrm{~mm}\end{array}$ & $\begin{array}{l}5 \% \text { acrylamide } \\
\text { acryl } / \text { bis }=30: 0.75 \\
0.1 \% \mathrm{SDS} \\
20 \mathrm{~mm}\end{array}$ \\
\hline $\begin{array}{l}\text { Separation gel buffer } \\
\text { Separation gel }\end{array}$ & $\begin{array}{l}\text { Tris- } \mathrm{HCl}, \mathrm{pH} 9.00 \\
\text { gradient } 12-18 \% \\
\text { acryl } / \text { bis }=30: 0.8 \\
0.1 \% \text { SDS }\end{array}$ & $\begin{array}{l}\text { Tris-HC1, pH } 8.90 \\
\text { gradient } 12-18 \% \\
\text { acryl } / \text { bis }=30: 0.8 \\
0.1 \% \mathrm{SDS}+6 \mathrm{M}-\mathrm{urea}\end{array}$ & $\begin{array}{l}\text { Tris-sulphate. pH } 9.00 \\
\text { gradient } 10-20 \% \\
\text { acryl } / \text { bis }=30: 0.75 \\
0.1 \% \text { SDS }\end{array}$ \\
\hline Lower reservoir buffer & Tris- $\mathrm{HCl}, \mathrm{pH} 9.18$ & borate-HCl, $\mathrm{pH} 8.00$ & Tris-glycine, $\mathrm{pH} 9.00$ \\
\hline $\begin{array}{l}\text { Gel length } \\
\text { Gel thickness } \\
\text { Temperature } \\
\text { Current (initial) } \\
\text { (after penetration) }\end{array}$ & $\begin{array}{l}22 \mathrm{~cm} \\
0.95 \mathrm{~mm} \\
18^{\circ} \mathrm{C} \\
1 \mathrm{~mA} / 100 \mathrm{~mm}^{2} \\
3.5 \mathrm{~mA} / 100 \mathrm{~mm}^{2}\end{array}$ & $\begin{array}{l}22 \mathrm{~cm} \\
0.95 \mathrm{~mm} \\
18^{\circ} \mathrm{C} \\
2.5 \mathrm{~mA} / 100 \mathrm{~mm}^{2} \\
12 \mathrm{~mA} / 100 \mathrm{~mm}^{2}\end{array}$ & $\begin{array}{l}15 \mathrm{~cm} \\
2.4 \mathrm{~mm} \\
5^{\circ} \mathrm{C} \\
1 \mathrm{~mA} / 100 \mathrm{~mm}^{2} \\
7 \mathrm{~mA} / 100 \mathrm{~mm}^{2}\end{array}$ \\
\hline
\end{tabular}

$30 \mathrm{~min}$ in $10 \%$ trichloroacetic acid prior to photographing. SDS (Ferak) was recrystallised from ethanol before use. Acrylamide, N,N'methylene-bis-acrylamide and Coomassie brilliant blue were obtained from Sigma and used without further purification.

The apparent molecular weight of the various chlorophyll-proteins and their polypeptide components were calculated using the following values for known polypeptides of wild-type barley (37): chlorophyll a-protein 1 (110kD), chlorophyll $a$-protein 1 apoprotein $(68 \mathrm{kD})$, coupling factor $1 \beta$ subunit $(57 \mathrm{kD})$, large subunit of ribulose-1,5-bisphosphate carboxylase $(55 \mathrm{kD})$, cytochrome $f(33 \mathrm{kD})$ and the small subunit of ribulose-1,5-bisphosphate carboxylase $(14 \mathrm{kD})$. These in turn had been calibrated using the following standards: bovine serum albumin $(68 \mathrm{kD})$, ovalbumin $(45 \mathrm{kD})$, aldolase $(40 \mathrm{kD})$ and chymotrypsinogen A $(25 \mathrm{kD})$.

\section{Table II}

Components of electrophoresis system IV

\begin{tabular}{llcc}
\hline & stacking gel $(5 \%)$ & separation gel (10\%) & separation gel (20\%) \\
\hline gel buffer $(\mathrm{ml})$ & 2.55 & 7.5 & 7.5 \\
sucrose $(\mathrm{g})$ & 0 & 1.5 & 5.25 \\
acrylamide $(\mathrm{ml})$ & 1.25 & 7.5 & 15.0 \\
ammonium persulphate $(\mu \mathrm{l})$ & 50 & 150 & 150 \\
water & to $10 \mathrm{ml}$ & to $30 \mathrm{ml}$ & to $30 \mathrm{ml}$ \\
\hline
\end{tabular}

Stock solutions:

gel buffer: Tris $(36.3 \mathrm{~g})$; $1 \mathrm{~N}-\mathrm{H}_{2} \mathrm{SO}_{4}(62 \mathrm{ml})$; TEMED $(0.48 \mathrm{ml})$; SDS $(0.80 \mathrm{~g})$ and water to $200 \mathrm{ml}$ acrylamide: acrylamide $(40 \mathrm{~g})$; bis-acrylamide $(1 \mathrm{~g})$ and water to $100 \mathrm{ml}$ ammonium persulphate: $100 \mathrm{mg} \cdot \mathrm{ml}^{-1}$

reservoir buffer: Tris $(121.0 \mathrm{~g})$; glycine $(115.6 \mathrm{~g})$ and water to $1000 \mathrm{ml}$ upper reservoir buffer: Tris-glycine stock $(21.0 \mathrm{ml})$; SDS $(0.5 \mathrm{~g})$ and water to $500 \mathrm{ml}$ lower reservoir buffer: Tris-glycine stock $(168.0 \mathrm{ml})$ and water to $4000 \mathrm{ml}$ solubilisation buffer: gel buffer stock plus SDS (10\%) 


\subsection{Isolation of the light-harvesting complex (LHC)}

The light-harvesting chlorophyll $a / b$-protein complex (LHC) from barley was isolated and purified according to the method of BURKE, DitTo \& ARnTzen (6) and stored in $30 \%$ glycerol at $-15^{\circ} \mathrm{C}$ until needed.

\section{RESULTS}

\subsection{Wild-type thylakoids}

Ten chlorophyll-protein bands, plus free chlorophyll, could be resolved when purified wild-type barley thylakoids solubilised with a limiting amount of SDS, as described in section 2.3 , were subjected to $6 \mathrm{~h}$ of electrophoresis using the Tris-glycine/Tris-sulphate system (Figure 1a). It can be seen that there are at least seven chlorophyll-containing bands with electrophoretic mobilities between $\mathrm{Chl}_{\mathrm{a}}-\mathrm{Pl}$ (CPI) and $\mathrm{Chl}_{\mathrm{a} / \mathrm{b}}$-P2 (CPII).

Since metalloporphyrins, such as chlorophyll, usually fluoresce red when illuminated with ultra-violet light, the gel was also photographed under conditions suitable for visualising fluorescence. This resulted in the type of image seen in Figure $1 \mathrm{~b}$, where each chlorophyll-containing band in Figure la has given rise to a red fluorescing band, except for $\mathrm{Chl}_{\mathrm{a}} \mathrm{-Pl}$ (CPI). Fixation of the gel in $7 \%$ acetic acid converted metalloporphyrins to the free base, which also fluoresces red (14), and the resulting image is seen in Figure 1c. It can now be seen that $\mathrm{Chl}_{\mathrm{a}}$ $\mathrm{Pl}$ (CPI) is fluorescent and there are several extra fluorescent bands not seen in Figure $1 \mathrm{~b}$, and which do not correspond to chlorophyll-containing bands in Figure la. Figure Id shows the polypeptide bands in the same gel, as revealed by Coomassie brilliant blue staining after fixation.

\subsection{Isolated light-harvesting complex (LHC)}

The multiplicity of chlorophyll-protein bands from wild-type barley thylakoids led us to examine systems with less complexity in order to attempt an identification of some of these bands. The purified light-harvesting complex from barley contains mainly $\mathrm{Chl}_{\mathrm{a}} / \mathrm{b}-\mathrm{P} 2$ (CPII) and a minor amount of non-chlorophyll-protein material. When subjected to the same electrophoretic conditions as in Figure 1, up to four chlorophyll-protein bands were seen (Figure 2), although there were quantitative variations in the relative amounts of each of these bands from run to run. The patterns from two separate experiments are given in Figures $2 b$ and $2 \mathrm{e}$. By comparing the position of these bands with the Coomassie blue staining polypeptides in the wild-type pattern, it was possible to assign apparent molecular weights of $29 \mathrm{kD}, 50 \mathrm{kD}$, $71 \mathrm{kD}$ and $107 \mathrm{kD}$ to the four chlorophyllcontaining bands from light-harvesting complex. The absorption spectra of these bands are presented in Figure 3. They all showed high levels of chlorophyll $b$, although there were differences in the chlorophyll $a$ to $b$ ratios and in the wavelengths of the maxima.

It was possible to correlate the chlorophyllprotein bands from the isolated light-harvesting complex with some of the bands present in wildtype thylakoids (Figure 2a and 2b). The band with an apparent molecular weight of $71 \mathrm{kD}$ $\left(\mathrm{Chl}_{\mathrm{a} / \mathrm{b}}-\mathrm{P} 2^{* *}\right)$ was clearly visible in the wild-type pattern and the absorption spectra are similar (Figures 3 and 6). The two minor bands $\left(\mathrm{Ch}_{\mathrm{a} / \mathrm{b}^{-}}\right.$ $\mathrm{P} 2^{* * *}$ and $\left.\mathrm{Chl}_{\mathrm{a} / \mathrm{b}}-\mathrm{P} 2^{*}\right)$ of the light-harvesting complex are obscured in the wild-type pattern by $\mathrm{Chl}_{\mathrm{a}} \mathrm{-Pl}$ and $\mathrm{Chl}_{\mathrm{a}}-\mathrm{P} 2$.

\subsection{Chlorina- $f 2$ mutant}

The nature of some of the other chlorophyllprotein bands in the wild-type pattern was investigated by a comparison with the pattern from the nuclear gene mutant chlorina- $f 2$. This mutant contains no chlorophyll $b(5)$, so any chlorophyll-protein bands present would contain only chlorophyll $a$. When the pattern from these thylakoids was examined, the major difference was the expected absence of the $\mathrm{Chl}_{\mathrm{a} / \mathrm{b}}-\mathrm{P} 2$ (CPII) band (Figure 4). In addition, Figure 4 illustrates that several other bands were missing, including those of low electrophoretic mobility associated with LHC. The main bands present are those designated $\mathrm{Chl}_{\mathrm{a}}-\mathrm{Pl}(\mathrm{CPI}), \mathrm{Chl}_{\mathrm{a}}-\mathrm{P} 2$ and $\mathrm{Chl}_{\mathrm{a}}-\mathrm{P} 3$ (see Discussion for explanation of nomenclature) and two minor bands with mobilities slightly slower than $\mathrm{Ch}_{\mathrm{a}}-\mathrm{P} 2$. Absorption spectra of the three major bands (Figure 5) confirmed that they contained only chlorophyll $a$ and the wavelength at the absorption maximum was characteristic for each band. The absorption spectra of the wild-type chlorophyll-protein bands not found in 
Figure 1. Separation of wild-type barley thylakoid components by SDS-polyacrylamide gel electrophoresis using the Tris-glycine/Tris-sulphate system. All photographs are of the same gel and are enlarged 1.38 times. a). Chlorophyll-protein bands appear as green regions on the gel and are named according to the nomenclature summarised in Table III. b). Appearance of the gel illuminated with long wavelength UV light and photographed through a red filter. All chlorophyll-containing bands fluoresce red, except for $\mathrm{Chl}_{\mathrm{a}}-\mathrm{Pl}$ in which fluorescence is quenched by $\mathrm{P} 700$. The dark region in the $\mathrm{Ch}_{\mathrm{a} / \mathrm{b}} \mathrm{P} 2$ band results from self-absorption due to the high chlorophyll concentration. c). The same gel after fixation in $7 \%$ acetic acid. The $\mathrm{Chl}_{\mathrm{a}} \mathrm{-P} 1$ band is now fluorescent, due to the destruction of P700 and an additional band has appeared (arrowhead) which may be due to cytochrome $f$. Fixation has removed much of the free chlorophyll below $\mathrm{Chl}_{\mathrm{a}} / \mathrm{b}-\mathrm{P} 2$, revealing discrete fluorescent bands corresponding to the major polypeptide bands in Figure 1d. d). The polypeptide pattern revealed by staining with Coomassie brilliant blue R-250.

Figure 2. Identification of $\mathrm{Chl}_{\mathrm{a}} / \mathrm{b}-\mathrm{P} 2$ and its complexes by electrophoresis of isolated light-harvesting complex from wild-type barley. a). Chlorophyll-protein bands of wild-type barley thylakoids. b). Chlorophyll-protein bands of isolated light-harvesting complex run on the same gel. c). The fluorescence pattern from Figure $2 \mathrm{~b}$. d). The polypeptide pattern of the same gel after staining with Coomassie blue G-250. The band below $\mathrm{Chl}_{\mathrm{a} / \mathrm{b}}-\mathrm{P} 2$ is thought to be a contaminant and was not seen in every gel run. $\mathrm{e}, \mathrm{f}, \mathrm{g}$ ). Gels from another electrophoretic separation of light-harvesting complex, corresponding to Figures $2 b, c$ and $d$ respectively. On this occasion there was a higher amount of $\mathrm{Ch} l_{\mathrm{a} / \mathrm{b}}-\mathrm{P} 2 *{ }^{*}$.



Figure 3. Absorption spectra of the chlorophyll-containing bands seen in Figure $2 \mathrm{~b}$ measured in the gel. The peak wavelength values for $\mathrm{Chl}_{a} / \mathrm{b}-\mathrm{P} 2^{*}{ }^{*}$ differ from those of $\mathrm{Chl}_{a} / \mathrm{b}-\mathrm{P} 2$. There is a decrease in the chlorophyll $a /$ $b$ ratio as one goes from the top to the bottom of the $\mathrm{Chl}_{\mathrm{a}} / \mathrm{b}-\mathrm{P} 2$ band, and a high chlorophyll $a / b$ ratio in the free chlorophyll band, indicating a selective loss of chlorophyll $a$ from $\mathrm{Chl}_{\mathrm{a}} / \mathrm{b}-\mathrm{P} 2$ during electrophoresis. 
Figure 4. Comparison of the chlorophyll-protein band patterns of wild-type barley and the chlorina- $f 2$ mutant which lacks chlorophyll $b$. As in Figure 2, the same two tracks from the same gel are shown to compare the chlorophyll-protein bands, the fluorescent bands and the Coomassie G-250 staining polypeptide patterns. The chlorina- $f 2$ mutant contains $\mathrm{Chl}_{\mathrm{a}}-\mathrm{P} 1, \mathrm{Ch}_{\mathrm{a}}-\mathrm{P} 2$ and $\mathrm{Chl} \mathrm{a}_{\mathrm{a}} \mathrm{P} 3$ and a minor $\mathrm{Chl}-\mathrm{P}$ band above $\mathrm{Chl}_{\mathrm{a}}-\mathrm{P} 2$ (arrowhead). This band immediately above $\mathrm{Chl}_{\mathrm{a}} \mathrm{P} 2$, which does not seem to correspond to a Chl-P band in Figure 1, may be an electrophoretic artefact causing free chlorophyll to focus at this point. The absence of $\mathrm{Chl}_{\mathrm{a}} / \mathrm{b}-\mathrm{P} 2^{*}$ improves the resolution of $\mathrm{Ch}_{\mathrm{a}}-\mathrm{P} 2$ and $\mathrm{Ch}_{\mathrm{a}}-\mathrm{P} 3$ in the chlorina- 2 pattern. Since this mutant is photosynthetically competent, and $\mathrm{Chl}_{\mathrm{a}} \mathrm{Pl}$ is known to contain the reaction centre of photosystem $\mathrm{l}$. it follows that the reaction centre of photosystem II is probably associated with $\mathrm{ChI}_{\mathrm{a}}-\mathrm{P} 2$ and/or $\mathrm{Chl}_{\mathrm{a}}-\mathrm{P} 3$.

the chlorina $-f 2$ mutant pattern reveal a peak or shoulder at $654 \mathrm{~nm}$, indicating the presence of chlorophyll $b$ (Figure 6). The chlorophyll $b$ in $\mathrm{Chl}_{\mathrm{a}}-\mathrm{P} 2$ from wild-type was probably due to contamination by the $50 \mathrm{kD}$ chlorophyll-protein band associated with LHC (Figure 2), since the absorption spectrum from the corresponding band from chlorina- $f 2$ shows no chlorophyll $b$ shoulder (Figure 5). There were three chlorophyll-containing bands in the wild-type pattern that were not found in chlorina- $f 2$ or isolated
LHC. These bands have been designated $\mathrm{Chl}_{\mathrm{a} / \mathrm{h}^{-}}$ Pl and Chl-P bands (see Discussion). Thus electrophoresis of wild-type barley thylakoids yields three chlorophyll $a$-proteins, two chlorophyll $a / b$-containing bands, three extra bands associated with one of these (in LHC), and two uncharacterised chlorophyll-containing bands.

Since oligomeric forms of CPII were found in the Tris-glycine/Tris-sulphate gel system (Figure 2), it was necessary to establish that $\mathrm{Chl}_{\mathrm{d}}-\mathrm{P} 2$ and $\mathrm{Chl}_{\mathrm{a}} \mathrm{P} 3$ are unique chlorophyll-proteins and not



Figure 5. Absorption spectra of the chlorophyll $a$-proteins of chlorina- $f 2$ recorded in situ in the gel. Note that each band has a characteristic peak wavelength value. 




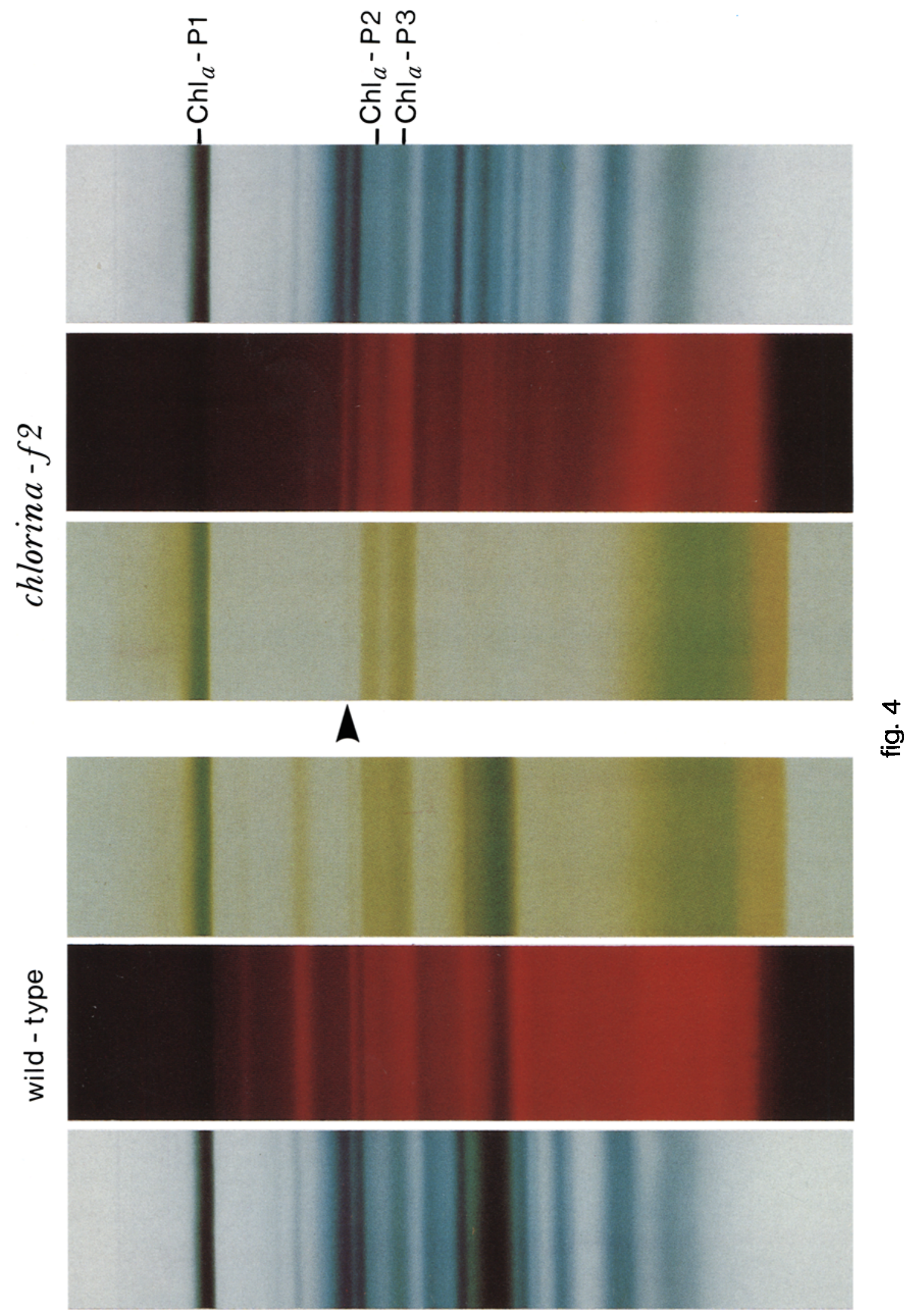






Figure 6. Absorption spectra of the chlorophyll-containing bands of wild-type barley not present in chlorina-f2. All these bands contain chlorophyll $b$ and probably have a light-harvesting or light-focusing role for the photosynthetic reaction centres. Also shown is the spectrum of $\mathrm{Ch} \mathrm{a}_{\mathrm{a}} \mathrm{P} 2$ showing a chlorophyll $b$ shoulder due to the presence of $\mathrm{Chl}_{\mathrm{a}} / \mathrm{b}-\mathrm{P} 2{ }^{*}$ in this region of the gel. Chl-P is the band in Figure 1 just below $\mathrm{Chl} a / \mathrm{h}^{-} \mathrm{P} 2^{* * *}$.

derived from other chlorophyll-proteins. The green bands corresponding to $\mathrm{Chl}_{\mathrm{a}}-\mathrm{P} 2$ and $\mathrm{Chl}_{\mathrm{a}}$ P3 were cut out from 3 preparative gels of SDSsolubilised chlorina $f 2$ thylakoids and the protein extracted and concentrated as described in section 2.4. This mutant was chosen instead of the wild-type because in the mutant, $\mathrm{Chl}_{\mathrm{a}}-\mathrm{P} 2$ and $\mathrm{Chl}_{\mathrm{a}}-\mathrm{P} 3$ are well resolved and not contaminated by the $50 \mathrm{kD}$ band derived from LHC. The polypeptide composition of the isolated chlorophyll-proteins is shown in Figure 7 and can be compared with the total thylakoid pattern of chlorina- $f 2$ electrophoresed under 2 different gel conditions (see Table I). Chl $-\mathrm{P} 2$ contained the $55 \mathrm{kD}$ large subunit of ribulose-1,5-bisphosphate carboxylase (probably due to insufficient washing of the thylakoids) and two bands of higher electrophoretic mobility. These two bands were also present in isolated $\mathrm{Chl}_{\mathrm{a}} \mathrm{-} \mathrm{P}$, but with an enrichment of the faster moving polypeptide as judged by relative staining intensity. Calculation of the molecular weights of these polypeptides yielded values of $49 \mathrm{kD}$ and $45 \mathrm{kD}$ in system II, and $47 \mathrm{kD}$ and $41 \mathrm{kD}$ in system III for the slower and faster moving polypeptides respectively. It was therefore concluded that the slower of the 2 bands corresponded to the protein moiety of $\mathrm{Chl}_{\mathrm{a}}-\mathrm{P} 2$ and the faster moving band to the protein moiety of $\mathrm{Chl}_{\mathrm{a}}-\mathrm{P} 3$. 
Figure 7. Re-electrophoresis of $\mathrm{Chl}_{\mathrm{a}}-\mathrm{P} 2$ and $\mathrm{Chl}_{\mathrm{a}}-\mathrm{P} 3$ isolated from preparative gels of chlorina- $f 2$ thylakoids. The polypeptide composition is compared with that of the total pattern of wild-type and chlorina $-f 2$ barley in two different gel systems. It is clear that the $\mathrm{Chl}_{\mathrm{a}} \mathrm{P} 2$ preparation is contaminated with the large subunit (LSU) of ribulose-1,5-bisphosphate carboxylase. It is tentatively concluded that the slower moving of the other two bands (arrows) is the apoprotein of $\mathrm{Chl}_{\mathrm{a}} \mathrm{-P} 2$ and the faster moving band is the apoprotein of $\mathrm{Chl}_{\mathrm{a}}-\mathrm{P} 3$. (SSU $=$ small subunit of ribulose-1,5bisphosphate carboxylase).

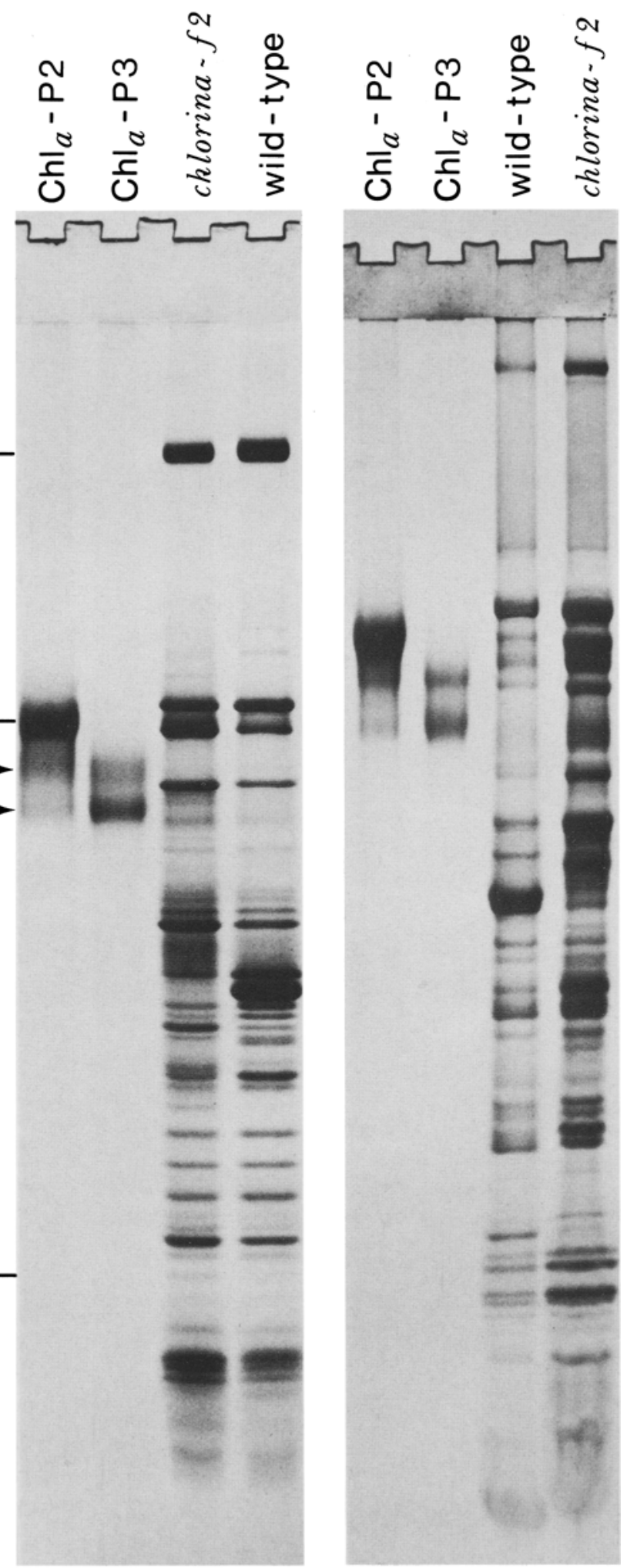




\subsection{Viridis mutants}

Additional evidence for the identity of the protein moieties of $\mathrm{Chl}_{\mathrm{a}} \mathrm{P} 2$ and $\mathrm{Chl}_{\mathrm{a}}-\mathrm{P} 3$ was sought by studying the chlorophyll-protein composition and polypeptide patterns of certain nuclear gene mutants of barley. The mutants viridis $-m^{29},-n^{34}$ and $-z d^{69}$ were chosen on the basis of their high chlorophyll content and known photosynthetic deficiencies $(31,37)$. It was reasoned that these mutants, which are single gene mutations from wild-type barley, might be lacking $\mathrm{Chl}_{\mathrm{a}}-\mathrm{P} 2$ and/or $\mathrm{Chl}_{\mathrm{a}}-\mathrm{P} 3$ and this might be correlated with the polypeptide pattern, which was not expected to be greatly different from that of wild-type barley thylakoids. The chlorophyll-protein band pattern, the fluorescent band pattern and the Coomassie blue staining polypeptide bands, all from the same gel, are shown in Figure 8. All 3 mutants contained $\mathrm{Ch}_{\mathrm{a}}-\mathrm{P} 3$, but only viridis $-m^{29}$ lacked a chlorophyll-protein band in the region corresponding to $\mathrm{Chl}_{\mathrm{a}} \mathrm{-} 2 \mathrm{P}$.

The polypeptide compositions of the purified thylakoids isolated from wild-type and the 4 mutants of barley were examined using high resolution polyacrylamide gel electrophoresis, both with and without $6 \mathrm{M}$-urea. The presence of urea improves the separation of polypeptides in the low molecular weight region. The positions of polypeptides corresponding to the protein moieties of $\mathrm{Chl}_{\mathrm{a}}-\mathrm{P} 2$ and $\mathrm{Chl}_{\mathrm{a}}-\mathrm{P} 3$, as predicted from re-electrophoresis of the isolated material (Figure 7), are indicated in Figure 9. These bands are characteristically diffuse (compare with the apoprotein of $\mathrm{Chl}_{\mathrm{a}}-\mathrm{Pl}$ (CPI) in Figure 9), but the polypeptide from $\mathrm{Chl}_{\mathrm{a}}-\mathrm{P} 3$ can be seen in all 4 mutants. The polypeptide of $\mathrm{Chl}_{\mathrm{a}} \mathrm{-} 2 \mathrm{P}$ was particularly intense in chlorina- $f 2$, and could readily be seen in the wild-type and viridis- $n^{34}$ patterns (figure 9). It was strongly reduced in intensity or missing from the viridis $-m^{29}$ and viridis $-z d^{69}$ patterns.

\section{DISCUSSION}

Ten chlorophyll-containing bands can be reproducibly obtained from SDS-solubilised thylakoids of wild-type barley using the polyacrylamide gel electrophoresis system described in this paper. Five of these bands are unique in their polypeptide composition and absorption spectra. It is useful when describing these different bands to refer to each one by a specific name. Since many workers have more or less simultaneously discovered, and named, new chlorophyll-containing bands in the past 2-3 years, there is no uniform system of nomenclature. Not only has the same chlorophyll-protein been called different names by various authors, but sometimes the same name has been given to two different bands (see Table III). It is evident from the data presented in this paper that no single nomenclature system published to date is adequate for classifying the different chlorophyll-containing bands of barley thylakoids. Therefore, the following nomenclature system for the chlorophyll-containing bands separated by SDS-polyacrylamide gel electrophoresis has been adopted:

Chlorophyll-protein: This term is used for those chlorophyll-containing bands which are sufficiently well characterised to establish that they have a unique polypeptide composition. It is helpful if, in addition, a chlorophyll-protein can be shown to be antigenically unrelated to all other chlorophyll-containing bands $(9,12)$. In the case where several chlorophyll-containing bands can be shown to consist of identical polypeptides, the band with the highest electrophoretic mobility (i.e., the lowest apparent molecular weight) is called a chlorophyll-protein. Such a band can be expected to represent the monomeric state. The chlorophyll-proteins so far discovered can be divided into two classes: those containing only chlorophyll $a$, and those containing both chlorophyll $a$ and $b$. The different

Figure 8. Comparison of the chlorophyll-protein patterns of wild-type barley and the three nuclear gene mutants viridis $-m^{29}$, viridis $-n^{34}$ and viridis $-z d^{69}$. Also shown are the fluorescent band patterns and polypeptide patterns from the same gels. The main feature of this figure is the absence of $\mathrm{Chl}_{\mathrm{a}}-\mathrm{P} 2$ from the mutant viridis- $m^{29}$, which although deficient in photosystem II, has sufficient activity to enable the plant to live. This is evidence that the reaction centre of photosystem II lies in $\mathrm{Chl}_{\mathrm{a}} \mathrm{P} 3$. 

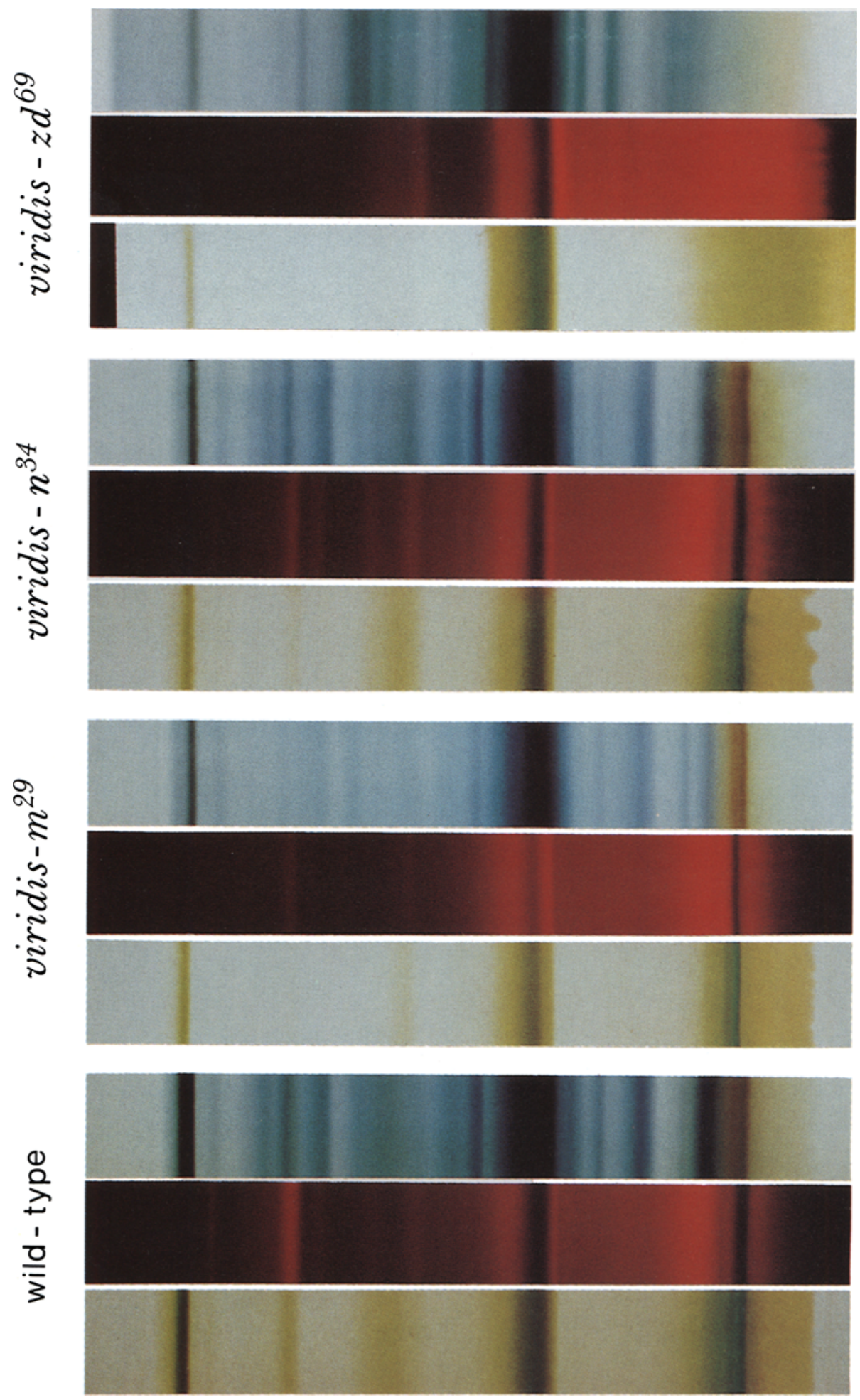


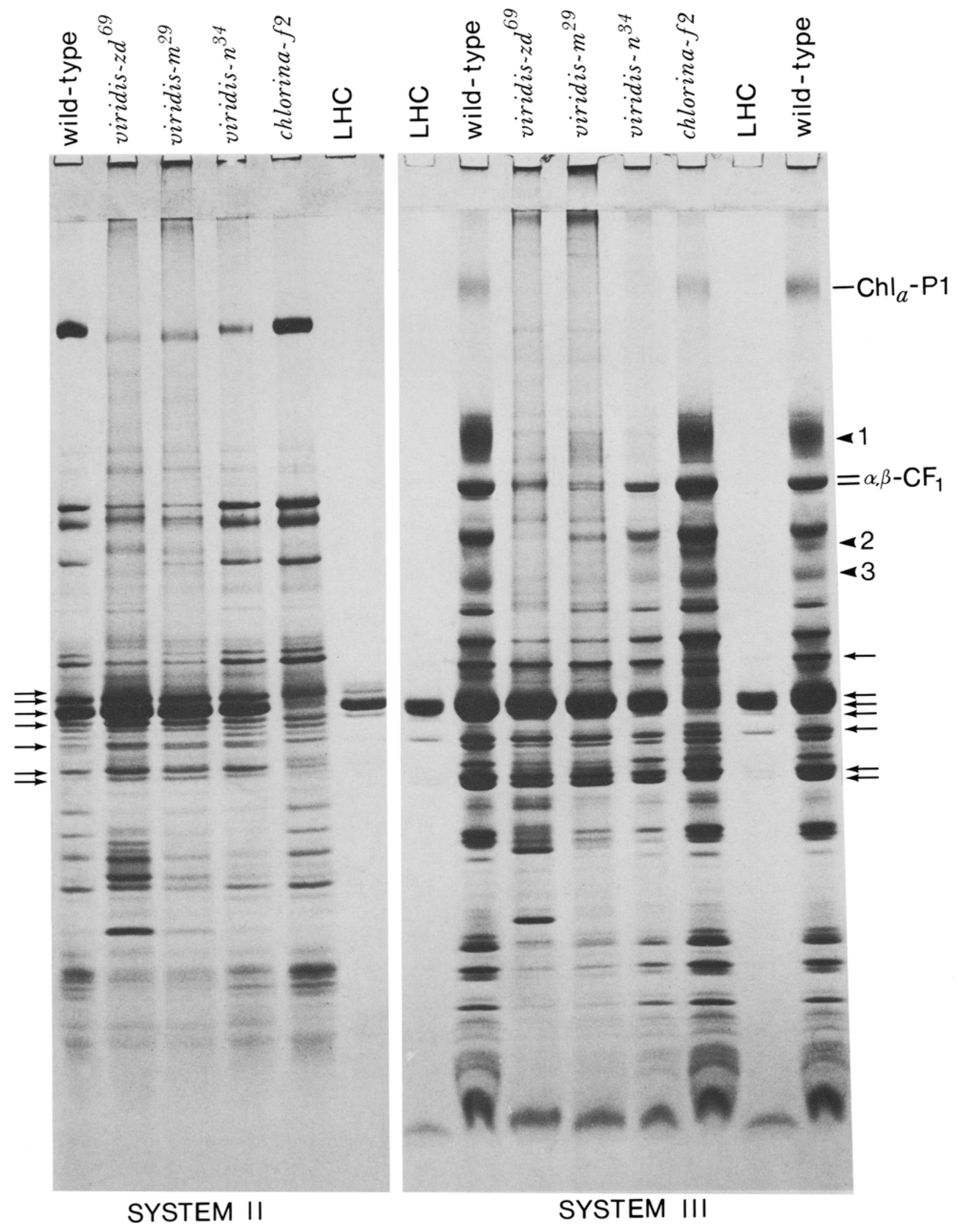


Figure 9. The polypeptide composition of wild-type barley and the four nuclear gene mutants examined in this paper, as well as isolated LHC, is compared in two different gel systems. The position of $\mathrm{Chl}_{\mathrm{a}} \mathrm{P} \mathrm{P}$ and the $\alpha$ and $\beta$ subunits of chloroplast coupling factor $1\left(\mathrm{CF}_{1}\right)$ are indicated, as is the position of the apoproteins of $\mathrm{Chl}_{\mathrm{a}}-\mathrm{Pl}$, $\mathrm{Ch}_{\mathrm{a}}-\mathrm{P} 2$ and $\mathrm{Chl}_{\mathrm{a}}-\mathrm{P} 3$ (arrowheads I, 2 and 3 respectively). The arrows indicate those bands in the total wild-type pattern that are found in isolated light-harvesting complex ( $\mathrm{LHC}$ ). Some of the minor bands are considered to be contaminants. The thylakoids were well-washed, to remove as much of the ribulose-1,5-bisphosphate carboxylase as possible since the large subunit of this protein has an electrophoretic mobility close to that of the apoprotein of $\mathrm{Chl}_{\mathrm{a}}-\mathrm{P} 2$. Of particular interest is the absence of the band corresponding to the apoprotein of $\mathrm{Chl}_{\mathrm{a}}-$ $\mathrm{P} 2$ from the viridis $-\mathrm{m}^{29}$ pattern. This mutant also lacks the green band corresponding $10 \mathrm{Chl} \mathrm{a}_{\mathrm{a}} \mathrm{P} 2$.

chlorophyll a-containing chlorophyll-proteins are designated $\mathrm{Chl}_{\mathrm{a}}-\mathrm{P} 1, \mathrm{Chl}_{\mathrm{a}}-\mathrm{P} 2$ and $\mathrm{Chl}_{\mathrm{a}}-\mathrm{P} 3$ in order of increasing electrophoretic mobility. Chlorophyll-proteins containing both chlorophyll $a$ and $b$ are, in the same way, designated $\mathrm{Chl}_{\mathrm{a} / \mathrm{b}}-\mathrm{Pl}$ and $\mathrm{Chl}_{\mathrm{a} / \mathrm{b}}-\mathrm{P} 2$ (Figure 1 and Table III). Where spectral or other evidence has indicated a function or property of a chlorophyll-protein, this can be incorporated into the name e.g., P-700 chlorophyll $a$-protein 1 and light-harvesting chlorophyll $a / b$-protein 2 .

Apoprotein: There are no covalent bonds between chlorophyll and the protein moiety of higher plant chlorophyll-proteins since chlorophyll can be dissociated from the protein under relatively mild conditions, such as brief boiling. The polypeptide to which the chlorophyll is attached is called the apoprotein of the chlorophyllprotein. When there is only a single polypeptide component of a chlorophyll-protein, there is no ambiguity in identifying it as the apoprotein of the chlorophyll-protein. If a chlorophyll-protein dissociates into two (or more) polypeptides upon denaturation, one or both might be apoproteins. Usually an apoprotein will have a different electrophoretic mobility from the native chlorophyll-protein. The size of the difference is the result of the relative contributions of two opposing phenomena: substitution of SDS for chlorophyll produces a higher charge/mass ratio and a higher electrophoretic mobility, while denaturation and unfolding of the polypeptide chain increases its Stokes radius and lowers the electrophoretic mobility. Thus if a purified chlorophyll-protein yields two polypeptides which have a mobility slightly different from that of the chlorophyll-protein, both polypeptides may be considered to be apoproteins. The implication then, is that the original chlorophyllcontaining band consists not of one, but two different chlorophyll-proteins with identical electrophoretic mobility. If one polypeptide has the same mobility as the original chlorophyllprotein, the possibility that it is a contaminant co-migrating with the chlorophyll-protein must be considered. The presence of several polypeptides, one or more of which has a mobility much lower than the original chlorophyll-protein, is more difficult to interpret and may mean that in the native state, an apoprotein plus chlorophyll is complexed with non-chlorophyll-containing polypeptides by bonds that are stable in the presence of SDS (see below).

The apoprotein of a chlorophyll-protein may be abbreviated by inserting a capital ' $A$ ' in the abbreviation for the corresponding chlorophyllprotein. Thus the apoprotein of chlorophyll $a$ protein $1\left(\mathrm{Chl}_{\mathrm{a}}-\mathrm{Pl}\right)$ is abbreviated to $\mathrm{Chl}_{\mathrm{a}}-\mathrm{APl}$, and the apoprotein of chlorophyll $a / b$-protein 2 $\left(\mathrm{Chl}_{a / b}-\mathrm{P} 2\right)$ is represented by $\mathrm{Chl}_{\mathrm{a} / \mathrm{b}}-\mathrm{AP} 2$, and so on.

Only five of the chlorophyll-containing bands from barley thylakoids can be classified as chlorophyll-proteins (Figure 1 and Table III). The P700-chlorophyll a-protein $1\left(\mathrm{Chl}_{\mathrm{a}}-\mathrm{Pl}\right)$ has an apparent molecular weight of $110 \mathrm{kD}$ and an apoprotein of $68 \mathrm{kD}$ (Figure 7). The antenna chlorophylls in this band do not fluoresce, indicating the presence of an efficient quencher. This is likely to be P700, since it has been shown to be present in the $\mathrm{Chl}_{\mathrm{a}}-\mathrm{Pl}$ band from tobacco thylakoids $(19,26)$. Conversion of the P700 chlorophylls to pheophytin by acetic acid destroys the quenching ability and the antenna chlorophylls (pheophytins) can then emit red fluorescent light (Figure 1c). The highly efficient quenching of fluorescence from antenna chloro- 
Table III

Chlorophyll-protein nomenclature

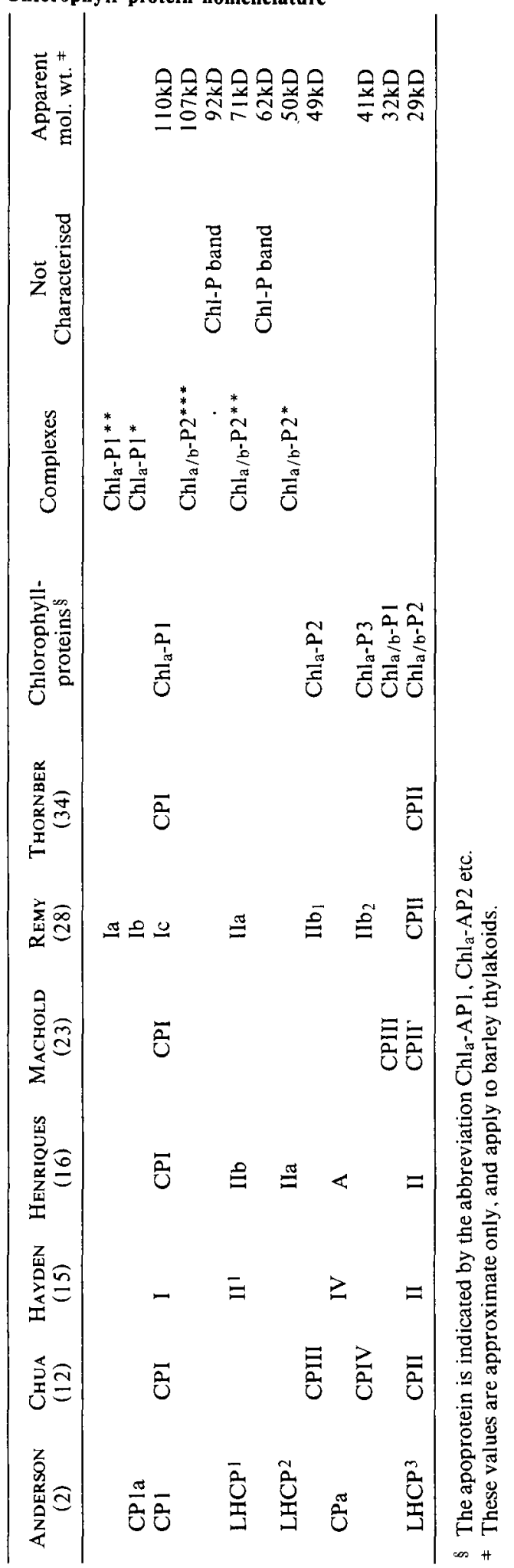

phyll indicates that $\mathrm{Chl}_{2}-\mathrm{Pl}$ has retained its native conformation, as previously indicated by its low temperature fluorescence emission spectrum (2) and P700 difference spectrum (28).

The apparent molecular weight of $\mathrm{Chl}_{\mathrm{a}} \mathrm{-P} 2$ is approximately $49 \mathrm{kD}$ and $\mathrm{Chl}_{\mathrm{a}} \mathrm{-} 3 \mathrm{P}$ has an apparent molecular weight of about $41 \mathrm{kD}$. The electrophoretic mobility of each of these chlorophyll-proteins is at least as high as their corresponding apoproteins, in contrast to $\mathrm{Chl}_{\mathrm{a}}$ $\mathrm{Pl}$ and its apoprotein. In Chlamydomonas (12) both of these chlorophyll-proteins $\left(\mathrm{Chl}_{\mathrm{a}}-\mathrm{P} 2\right.$ and $\mathrm{Chl}_{\mathrm{a}}-\mathrm{P} 3$ ) have a faster electrophoretic mobility than their corresponding apoproteins. These two chlorophyll-proteins are good candidates for the site of the reaction centre of photosystem II (P680), since along with $\mathrm{Chl}_{\mathrm{a}}-\mathrm{Pl}$ (the site of the reaction centre of photosystem I), these are the only major chlorophyll-proteins in the chlorina$f 2$ mutant (Figure 4). Ch1 ${ }_{\mathrm{a}}-\mathrm{P} 2$ is absent from the mutant viridis- $m^{29}$ (Figure 8), which although low in photosystem II activity (B. CARLSEN, cand. scient. thesis), is nevertheless autotrophic and will produce seeds under suitable growth conditions (7). It would therefore appear that $\mathrm{Chl}_{\mathrm{a}}-\mathrm{P} 3$ is the most likely site of the reaction centre of photosystem II. This band, also called CPIV (12), or complex $\mathrm{Ilb}_{2}$ (28), or a component of $\mathrm{CPa}(2)$, or $\mathrm{A}(16)$, or complex IV (15) has previously been implicated as being involved in photosystem II. In all instances, $\mathrm{Chl}_{\mathrm{a}}-\mathrm{P} 3$ lacks chlorophyll $b$ and has a chlorophyll absorption peak at $671 \mathrm{~nm}$ (Figure 5). Conclusive evidence for the site of the photosystem II reaction centre will come from the demonstration of P680 in this band, and/or a low temperature fluorescence emission peak at $695 \mathrm{~nm}$.

In Chlamydomonas $\mathrm{Chl}_{\mathrm{a}}-\mathrm{P} 2$ and $\mathrm{Chl}_{\mathrm{a}}-\mathrm{P} 3$ (called CPIII and CPIV respectively) each contain a single unique polypeptide (polypeptide 5 and 6 respectively) (12). The apoprotein of $\mathrm{Chl}_{\mathrm{a}}-\mathrm{P} 3$ (CPIV) in Chlamydomonas cross-reacts immunochemically with the apoprotein of barley $\mathrm{Chl}_{\mathrm{a}}-\mathrm{P} 3$ (31) and it is probable that the apoprotein of Chlamydomonas $\mathrm{Ch}_{\mathrm{a}}-\mathrm{P} 2$ (CPIII) corresponds to the apoprotein of barley $\mathrm{Chl}_{\mathrm{a}} \mathrm{P} 2$. Genetic evidence has indicated that polypeptide 6 , and possibly polypeptide 5 of Chlamydomonas, are involved in the reaction centre of photosystem II (8). Genetic (8) and inhibitor studies $(10)$ have shown that these polypeptides 
are coded for by chloroplast DNA and are translated on chloroplast ribosomes. Since viridis- $m^{29}$, which lacks $\mathrm{Ch}_{\mathrm{a}}-\mathrm{P} 2$, is a nuclear gene mutant, nuclear DNA is involved in the incorporation of $\mathrm{Chl}_{\mathrm{a}}-\mathrm{P} 2$ into the thylakoid membrane. The involvement of both chloroplastic and nuclear genes in the formation of another chlorophyll-protein $\left(\mathrm{Chl}_{\mathrm{a}}-\mathrm{Pl}\right)$ has already been reported $(4,11)$.

There are two chlorophyll $a / b$-proteins (Table III). Chlorophyll $a / b$-protein $1\left(\mathrm{Chl}_{\mathrm{a} / \mathrm{h}}-\mathrm{Pl}\right)$ has an electrophoretic mobility slightly lower than $\mathrm{Chl}_{\mathrm{a} / \mathrm{b}}-\mathrm{P} 2$ (Figure 1) and a higher chlorophyll $\mathrm{a} /$ $b$ ratio, but is not completely resolved in gel system IV. It has been shown with Vicia faba (23) that isolated $\mathrm{Chl}_{a / b}-\mathrm{Pl}$ is composed of a single polypeptide which has the same mobility as one of the two polypeptides of $\mathrm{Chl}_{\mathrm{a} / \mathrm{h}}-\mathrm{P} 2$. It has been demonstrated. however, that the $\mathrm{Chl}_{\mathrm{a} / \mathrm{h}^{-}}$ $\mathrm{Pl}$ apoprotein is different from the $\mathrm{Chl}_{\mathrm{a} / \mathrm{h}}-\mathrm{P} 2$ polypeptides by using the improved resolution of the urea gel system (23). The function of this chlorophyll-protein is not known, but its absence from the chlorina $f 2$ pattern (Figure 4 ) indicates that it is not essential for photosynthesis, but might play a role in light-harvesting or lightfocusing for photosystem I or II.

The light-harvesting chlorophyll $a / b$-protein $2\left(\mathrm{Chl}_{\mathrm{a} / \mathrm{b}}-\mathrm{P} 2\right)$ is the major chlorophyll-protein of wild-type thylakoids, containing about $50 \%$ of the total chlorophyll $(2,18)$ and most, but not all, of the chlorophyll $b$. It was originally believed to be the reaction centre of photosystem II, but since it is not found in the photosynthetically competent chlorina -2 mutant, it has been assigned a light-harvesting function (35). Its properties will be discussed below in connection with chlorophyll-protein complexes.

Chlorophyll-protein complexes: Originally the chlorophyll-containing bands separated by gel electrophoresis were called chlorophyll-protein complexes $(33,34)$, indicating that chlorophyll and a protein formed a complex. For some time it was thought that such bands on polyacrylamide gels were identical to chlorophyll-protein complexes isolated by detergent treatment of thylakoids followed by purification on sucrose gradients or by column chromatography. The use of the term 'complex' for both chlorophyllproteins and the preparations containing chloro- phyll-proteins associated with other polypeptides has led to confusion between, for example, lightharvesting chlorophyll $a / b$ protein complex (CPII or LHCP) and the light-harvesting complex (LHC), and between $\mathrm{Chl}_{\mathrm{a}}-\mathrm{Pl}$ (CPI) and photosystem I particles (3) containing $\mathrm{Chl}_{\mathrm{a}} \mathrm{-Pl}$.

The term chlorophyll-protein complex is limited here to a chlorophyll-protein associated with itself to form an oligomer, or with another chlorophyll-protein, or with non-chlorophyllcontaining polypeptides. A chlorophyll-containing band is designated a complex by placing one or more asterisks after the name of the chlorophyll-protein from which it is derived (see Table III). Many chlorophyll-protein complexes are isolated by gentle detergent treatment of thylakoids, yielding upon purification, a uniform population of particles consisting of stoichiometric quantities of a chlorophyll-protein and nonchlorophyll-containing proteins. Such complexes seem to exist within the thylakoid membrane as structural (and functional) units $(3,6)$. In addition, the tendency for some chlorophyllproteins to self-aggregate (6), may lead to the formation of artefactual higher order complexes that are stable under the conditions used for electrophoresis.

The chlorophyll-protein complexes related to $\mathrm{Chl}_{\mathrm{a} / \mathrm{h}}-\mathrm{P} 2$ were investigated by electrophoresis of the light-harvesting complex isolated by Triton$\mathrm{X} 100$ solubilisation and precipitation with $\mathrm{Mg}^{++}(6)$. When electrophoresed in system II (Figure 9) this preparation was resolved into one major polypeptide component of molecular weight $25 \mathrm{kD}$ and two minor bands at $26 \mathrm{kD}$ and $24 \mathrm{kD}$. The four bands at $27 \mathrm{kD}, 22 \mathrm{kD}, 20 \mathrm{kD}$ and $19 \mathrm{kD}$ are probably contaminants that coprecipitate during the isolation. The same preparation run in a urea gel (system III) yields two major bands at $27 \mathrm{kD}$ and $26 \mathrm{kD}$ with minor bands at $25 \mathrm{kD}$ and $24 \mathrm{kD}$ and probable contaminants at $31 \mathrm{kD}, 21 \mathrm{kD}$ and $20 \mathrm{kD}$ (Figure 9). It is difficult to make a direct correlation between the bands in the two different gels, but it seems probable that the major band in system II has been resolved into two bands in the urea system. There is indirect evidence from Vicia faba that $\mathrm{Chl}_{\mathrm{a} / \mathrm{b}}-\mathrm{P} 2$ consists of two distinct apoproteins and hence two chlorophyll-proteins (23). The chlorophyll $a / b$ ratio decreases as one moves down the $\mathrm{Ch} 1_{\mathrm{a} / \mathrm{b}}-\mathrm{P} 2$ band, but the relatively high 
chlorophyll $a / b$ ratio of the free chlorophyll (Figure 3) could mean that there is a selective loss of chlorophyll $a$ from $\mathrm{Chl}_{\mathrm{a} / \mathrm{b}}-\mathrm{P} 2$ during electrophoresis. While APEL (1) has found two components of the $\mathrm{Ch}_{\mathrm{a} / \mathrm{b}} \mathrm{P} 2$ complex in Acetabularia thylakoids, only one of them was considered to be an apoprotein. There is evidence, however, that the $\mathrm{Chl}_{\mathrm{a} / \mathrm{b}}-\mathrm{P} 2$ region of Chlamydomonas consists of several chlorophyllcontaining bands when electrophoresed at low temperature in the presence of lithium dodecyl sulphate ( 12 .

It is interesting that there is a small amount of red fluorescing material at the position of $\mathrm{Chl}_{\mathrm{a} / \mathrm{h}^{-}}$ P2 in the chlorina-f2. mutant (Figure 4) and that it has a chlorophyll a spectrum. The site of the primary lesion in chlorina- $f 2$ is not known, but in view of the absence of so many chlorophyll $b$ containing chlorophyll-proteins, it would appear to be the inability to convert chlorophyll $a$ to chlorophyll $b$. It is possible that without chlorophyll $b$, chlorophyll $b$-containing proteins are not synthesised, or fail to become incorporated into the thylakoid membrane.

The slower moving chlorophyll-protein complexes of $\mathrm{Chl}_{\mathrm{a}} / \mathrm{b}-\mathrm{P} 2$ have been designated $\mathrm{Chl}_{\mathrm{a} / \mathrm{h}^{-}}$ $\mathrm{P} 2{ }^{*}, \mathrm{Chl}_{\mathrm{a} / \mathrm{b}}-\mathrm{P} 2^{* *}$, and $\mathrm{Chl}_{\mathrm{a} / \mathrm{b}}-\mathrm{P} 2{ }^{* *}$, in order of increasing molecular weight (Table III). These are considered to be multimers of $\mathrm{Chl}_{\mathrm{a} / \mathrm{b}} \mathrm{P} 2$ on the basis of absorption spectra and polypeptide composition of both the complexes and the isolated light-harvesting complex. Although one might speculate that the complexes represent dimers, trimers and tetramers of $\mathrm{Chl}_{\mathrm{a} / \mathrm{h}}-\mathrm{P} 2$ on the basis of their apparent molecular weights $(29 \mathrm{kD}, 50 \mathrm{kD}, 71 \mathrm{kD}$ and $107 \mathrm{kD})$ it should be remembered that chlorophyll-proteins show anomolous electrophoretic behaviour in polyacrylamide gels (11). Since the actual method for purification of this material is based on $\mathrm{Mg}^{++}$-induced self-aggregation of $\mathrm{LHC}$, it is difficult to decide whether these complexes of $\mathrm{Chl}_{\mathrm{a} / \mathrm{b}}-\mathrm{P} 2$ are artefacts, or represent forms which are closer to the in vivo state, as suggested $(2,28)$ from spectral evidence.

On occasion, a chlorophyll-containing band was seen above $\mathrm{Chl}_{\mathrm{a}}-\mathrm{Pl}$, and on the basis of its fluorescence quenching is most likely a higher order complex of $\mathrm{Chl}_{\mathrm{a}}-\mathrm{P} . \mathrm{l}$, and should be designated $\mathrm{Chl}_{\mathrm{a}} \mathrm{-} \mathrm{P}^{*}$. Such complexes have been seen previously in tobacco (28) and spinach (2) and Vicia faba.

Chlorophyll-protein bands: It was agreed by participants of the EMBO Workshop on Chloroplast Membrane Polypeptides (Carlsberg Laboratory, Copenhagen, June 11, 1979) that a chlorophyll-containing region in polyacrylamide gels should be given the general name of chlorophyll-protein bands until sufficient evidence had accumulated to establish its identity as either a chlorophyll-protein or a chlorophyllprotein complex. In the case of barley thylakoids, there are two chlorophyll-containing protein bands, designated Chl-P (Figures $I$ and 6, Table III), that are not complexes of $\mathrm{Chl}_{\mathrm{a} / \mathrm{b}}-\mathrm{P} 2$ and have not yet been characterised sufficiently well to determine whether they are unique chlorophyll-proteins. They could be artefactual chlorophyil-containing bands formed by the focusing of free chlorophyll released from chlorophyllproteins, by ion boundaries or high local concentrations of polypeptides. The occurrence of the same red fluorescent bands between $\mathrm{Chl}_{\mathrm{a} / \mathrm{b}}$ $\mathrm{P} 2$ and free chlorophyll, in both wild-type and chlorina- 2 , may be the result of these phenomena, particularly since these bands correspond with the major Coomassie-staining polypeptide bands in this region of the gel (Figure 1). The appearance of a fluorescent band with a position between $\mathrm{Chl}_{2}-\mathrm{P} 3$ and $\mathrm{Chl}_{\mathrm{a}} / \mathrm{h}-\mathrm{Pl}$ after fixation in acetic acid, is consistent with the known electrophoretic mobility of barley cytochrome $f$ (37) which becomes fluorescent when converted to the free base.

\section{ACKNOWLEDGEMENTS}

We are grateful to professor DITER voN WETTSTEIN for valuable and stimulating discussions, and to Drs C. Gamini Kannangara and Verena Cameron-Mills for critically reviewing the manuscript. We thank AnN-Sori SteinHOLTZ, who is responsible for the high quality of the colour prints, and NINA RASMUSSEN for her skill in drawing the figures. Financial support was provided by the Commission of European Communities Contract 029-76-ES DK solar energy programme. 


\section{REFERENCES}

1. APEL, K.: The light-harvesting chlorophyll a/bprotein complex of the green alga Acetabularia mediterranea. Isolation and characterisation of two subunits. Biochim. Biophys. Acta 462, 390402 (1977)

2. Anderson, J. M., J. C. Wai.dron \& S. W. THORNE: Chlorophyll-protein complexes of spinach and barley thylakoids. Spectral characterisation of six complexes resolved by an improved electrophoretic procedure. FEBS Lett. 92, 227233 (1978)

3. Bengis, C. \& N. Nelson: Subunit structure of chloroplast photosystem I reaction center. J. Biol. Chem. 252, 4564-4569 (1977)

4. Bennoun, P., J. Girard \& N.-H. Chua: A uniparental mutant of Chlamydomonas reinhardtii deficient in the chlorophyll-protein complex CPI. Molec. Gen. Genet. 153, 343-348 (1977)

5. Boardman, N. K. \& H. R. Highkin: Studies on a barley mutant lacking chlorophyll $b$. I. Photochemical activity of isolated chloroplast. Biochim. Biophys. Acta 126, 189-199 (1966)

6. Burke, J. J., C. L. Ditto \& C. J. Arntzen: Involvement of the light-harvesting complex in cation regulation of excitation energy distribution in chloroplasts. Arch. Biochem. Biophys. $187,252-263$ (1978)

7. Carlsen, B.: Barley mutants with defects in photosynthetic carbon dioxide fixation. Carlsberg Res. Commun. 42, 199-209 (1977)

8. Chua, N.-H. \& P. Bennoun: Thylakoid membrane polypeptides of Chlamydomonas reinhardtii: Wild-type and mutant strains deficient in photosystem II reaction center. Proc. Nat. Acad. Sci. USA 72, 2175-2179 (1975)

9. Chua, N.-H. \& F. Blomberg: Immunochemical studies of thylakoid membrane polypeptides from spinach and Chlamydomonas reinhardtii. J. Biol. Chem. 254, 215-223 (1979)

10. Chua, N.-H. \& N. W. Gillham: The sites of synthesis of the principal thylakoid membrane polypeptides in Chlamydomonas reinhardtii. J. Cell Biol. 74, 441-452 (1977)

11. Chua, N.-H., K. Matuin \& P. Bennoun: A chlorophyll-protein complex lacking in photosystem I mutants of Chlamydomonas reinhardtii. J. Cell Biol. 67, 361-377 (1975)

12. Delepelaire, P.\& N.H. Chua: Lithium dodecyl sulfate/polyacrylamide gel electrophoresis of thylakoid membranes at $4{ }^{\circ} \mathrm{C}$ : Characterisations of two additional chlorophyll a-protein complexes. Proc. Nat. Acad. Sci. USA 76, 111-115 (1979)
13. Dunkley, P. R. \& J. M. Anderson: The lightharvesting chlorophyll $\mathrm{a} / \mathrm{b}$-protein complex from barley thylakoid membranes. Polypeptide composition and characterization of an oligomer. Biochim. Biophys. Acta 545, 174-187 (1979)

14. Fuнrhop, J.-H. \& K. M. Sмiтh: Laboratory Methods in Porphyrin and Metalloporphyrin Research. Elsevier Scientific Publ. Co., Amsterdam. (1975)

15. Hayden, D. B. \& W. G. Hopkins: A second distinct chlorophyll a-protein complex in maize mesophyll chloroplasts. Can. J. Bot. 55, 25252529 (1977)

16. Henriques, F. \& R. B. Park: Spectral characterization of five chlorophyll-protein complexes. Plant Physiol. 62, 856-860 (1978)

17. Herrmann, F. \& A. Meister: Separation and spectroscopical properties of pigment protein complexes in Antirrhinum chloroplasts. Photosynthetica $6,177-182(1972)$

18. Hiller, R. G., T. B. G. Pil.ger \& D. Campbeld: Extraction and stabilisation of the dimer of chlorophyll-protein complex II. Plant Sci. Lett. 14. 7-11 (1979)

19. Hoarau, J., R. Remy \& J.-C. Leci.erc: Hétérogeneité des variations spectrales photoinduites vers $700 \mathrm{~nm}$ observées sur les membranes chlorophylliennes et les complexes chiorophylleprotéines isolés de divers organismes photosynthetiques. Biochim. Biophys. Acta 462, 659-670 (1977)

20. Høyer-Hansen, G. \& D. J. Simpson: Changes in the polypeptide composition of internal membranes of barley plastids during greening. Carlsberg Res. Commun. 42. 379-389 (1977)

21. Kannangara, C. G., S. P. Gough, B. Hansen, J. N. RasmusSen \& D. J. Simpson: A homogenizer with replaceable razor blades for bulk isolation of active barley plastids. Carlsberg Res. Commun. 42, 431-439 (1977)

22. MACHOLD, O. \& A. Meister: Stability of chlorophyll-protein complexes in vitro. Biochem. Physiol. Pflanzen 174, 92-98 (1979)

23. MaChold, O. \& A. Meister: Resolution of the light-harvesting chlorophyll a/b-protein of Vicia faba chloroplasts into two different chlorophyllprotein complexes. Biochim. Biophys. Acta 546, 472-480 (1979)

24. Markwell. J. P., S. Reinman \& J. P. Thornber: Chlorophyll-protein complexes from higher plants: A procedure for improved stability and fractionation. Arch. Biochem. Biophys. 190 , 136-141 (1978) 
25. Markwell, J. P., J. P. Thornber \& R. T BoGGs: Higher plant chloroplast: evidence that all the chlorophyll exists as chlorophyll-protein complexes. Proc. Nat. Acad. Sci. USA 76. 1233-1235 (1979)

26. Mathis, P., K. Sauer \&, R. Remy: Rapidly reversible flash-induced electron transfer in a P-700 chlorophyll-protein complex isolated with SDS. FEBS Lett. 88. 275-278 (1978)

27. Ogawa, T., F. Obata \& K. Shibata: Two pigment proteins in spinach chloroplasts. Biochim. Biophys. Acta 112, 223-234 (1966)

28. Remy, R. \& J. Hoarau: New forms of chlorophyll-protein complexes from thylakoids of different photosynthesizing organisms. In: Chloroplast Development (Eds. G. Akoyunoglou et al.) Elsevier/North-Holland Biomed. Press. pp. 235-240 (1978)

29. Remy, R., J. Hoarau \& J. C. Leclers: Electrophoretic and spectrophotometric studies of chlorophyll-protein complexes from tobacco chloroplasts. Isolation of a light harvesting pigment protein complex with a molecular weight of 70,000. Photochem. Photobiol. 26. 151-158 (1977)

30. SAтоH, K.: Polypeptide composition of the purified photosystem II pigment-protein complex from spinach. Biochim. Biophys. Acta 546 , 84-92(1979)
31. Simpson, D. J., G. Høyer-Hansen, N.-H. Chua \& D. VON WETTSTEIN: The use of gene mutants in barley to correlate thylakoid polypeptide composition with the structure of the photosynthetic membrane. Proc. Fourth Internat. Congr. Photosyn., Reading pp. 537-548 (1977)

32. Studier, F. W.: Analysis of bacteriophage T7 early RNAs and proteins on slab gels. J. Mol. Biol. 79, 237-248 (1973)

33. ThORnber, J. P.: Chlorophyll-proteins: lightharvesting and reaction center components of plants. Ann. Rev. Plant Physiol. 26, 127-158 (1975)

34. Thornber, J. P., R. P. F. Gregory, C. A. Smith $\&$ J. L. BaIley: Studies on the nature of the chloroplast lamella. I. Preparation and some properties of two chlorophylt-protein complexes. Biochemistry 6, 391-396 (1967)

35. Thornker, J. P. \& H. R. HighKIN: Composition of the photosynthetic apparatus of normal barley leaves and a mutant lacking chlorophyll $b$. Eur. J. Biochem. 41, 109-116 (1974)

36. Wesseis. J. S. C. \& M. T. Borchert: Polypeptide profiles of chlorophyll-protein complexes and thylakoid membranes of spinach chloroplasts. Biochim. Biophys. Acta 503, 78-93 (1978)

37. Wettstein, D. von. B. L. Møller, G. HoyerHansen \& D. J. Simpson: Genetic manipulation of photosystem 1 and II in chloroplast membranes. EC Solar Energy R\&D Programme. 3rd Coordination Meeting of Contractors, June 18 20. Brussels (1979) 